\title{
Effect of Long Term Fertilization on Soil K Dynamics and Uptake by Hybrid Maize in an Irrigated Inceptisol under Intensive Cropping
}

\author{
Pragyan Paramita Rout $^{1 *}$, N. Chandrasekaran ${ }^{1}$, K. Arulmozhiselvan ${ }^{1}$ and \\ Dhaneshwar Padhan ${ }^{2}$
}
${ }^{1}$ Department of Soil Science and Agricultural Chemistry, Tamil Nadu Agricultural University, Coimbatore-641003, Tamil Nadu, India
${ }^{2}$ Dept. of Agricultural Chemistry \& Soil Science, Bidhan Chandra Krishi Viswavidyalaya, Nadia, West Bengal-741235, India
*Corresponding author

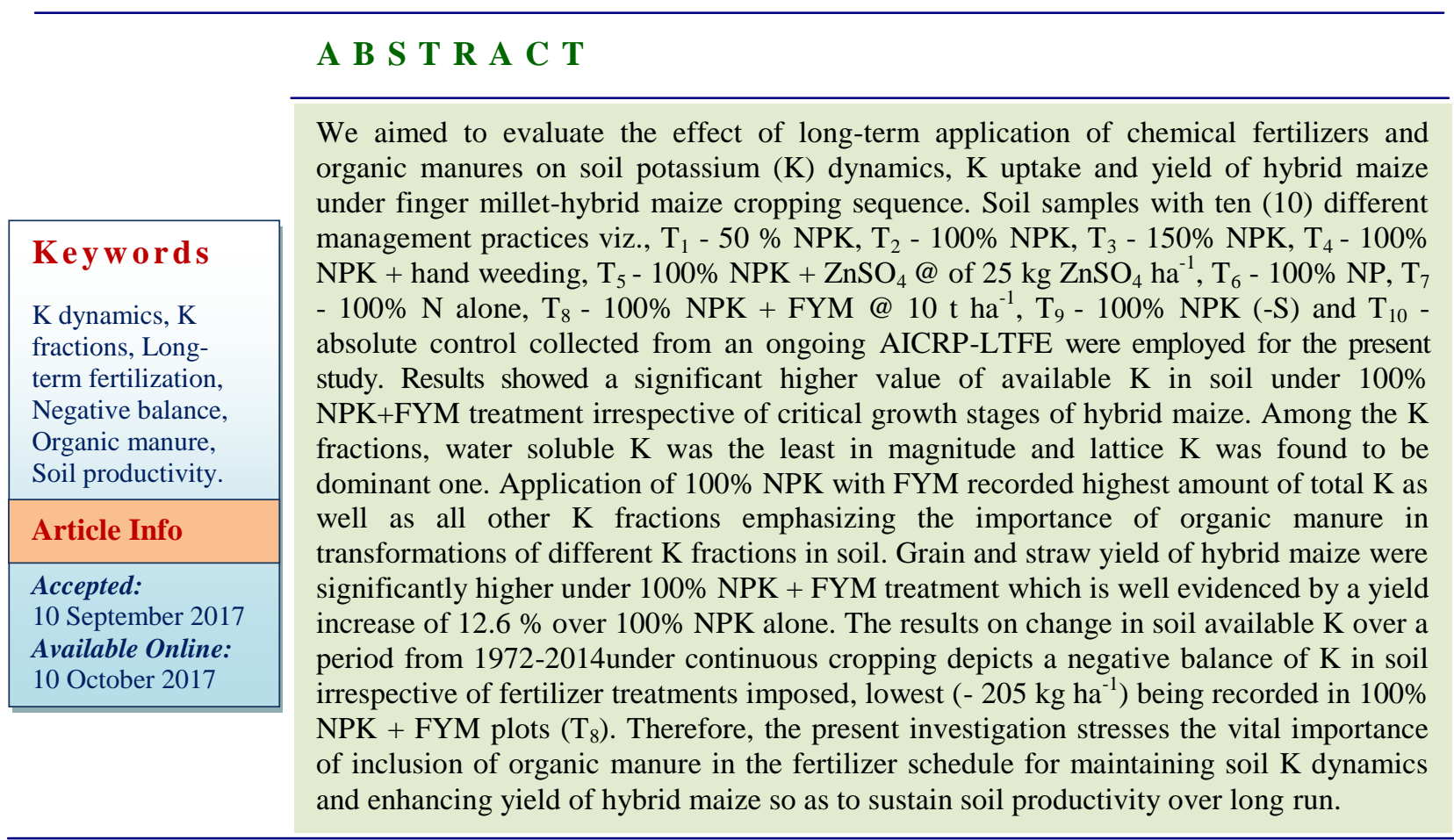

\section{Introduction}

Potassium $(\mathrm{K})$ is the third most important essential major plant nutrient with numerous functions. It plays a vital role in enzyme activation, osmotic regulation, energy relations, translocation of photosynthates, protein and starch synthesis there by underpinning agronomic productivity and sustainability (Mengel, 1985). Soil K exists in four different forms viz., water soluble-K, most frequently available form to plants; exchangeable-K, held by negative charges on soil colloids and is readily available to plants; non-exchangeable or fixed- $K$, which is trapped between layers of expanding lattice 
clays and lattice or structural-K, an integral part of primary $\mathrm{K}$ bearing minerals like mica or illite (Srinivasa Rao et al., 2001).

The total potassium content in soil depends on the type of parent material and degree of mineral weathering.

Where in, the availability of soil $\mathrm{K}$ to crops is controlled by the dynamic equilibrium among different K pools (Wang et al., 2004) that in turn depends on rate of application and mining of $\mathrm{K}$ from soil system (Singh et al., 2009).The knowledge of various forms of $K$ and an understanding condition controlling their availability to growing crops is an important for the appraisal of the available $\mathrm{K}$ in soil.

In most of the intensive cropping systems in India, potassium $(\mathrm{K})$ balance is negative since the additions of $\mathrm{K}$ seldom match the $\mathrm{K}$ removals resulting in larger dependence on native soil $\mathrm{K}$ supply from mineral reserve. Large removal of $\mathrm{K}$ that is now moderate or high in exchangeable $\mathrm{K}$, is likely to become potentially K-responsive or may get depleted, as is evident from the results of a number of longterm experiments conducted across the country (Brar and Pasricha, 1998).

Under such conditions there is higher mining of non-exchangeable $\mathrm{K}$ for meeting the $\mathrm{K}$ requirement of crops. Long-term intensive cropping, in the absence of $\mathrm{K}$ inputs, adversely affectK supply to crop plants and consequently crop yield (Swarup, 1998; Swarup and Ganeshmurthy, 1998).Hence, the knowledge about Kreserve in soil is necessary to understand potassium nutrition and its management for a sustained crop production. With this background, a field study was conducted to assess the effect of long term fertilization on soil $\mathrm{K}$ dynamics and $\mathrm{K}$ uptake by hybrid maize in an irrigated Inceptisol under intensive cropping.

\section{Materials and Methods}

\section{Experimental site, climate and soil type}

The present field study was conducted in the year 2013-2014 as a part of an ongoing All India Coordinated Research Project on Longterm Fertilizer Experiment (AICRP-LTFE) with finger millet-hybrid maize cropping sequence which was initiated during 1972 at Tamil Nadu Agricultural University, Coimbatore, Tamil Nadu. The soil of experimental site belongs to order-Inceptisol, having calcareous mixed black soil with sandy clay loam texture and comes under Vertic Ustropept. The initial soil properties are represented in Table 1.

\section{Treatment details}

There were ten treatments each replicated four times in Randomized Block Design viz., $\mathrm{T}_{1}-50$ $\% \mathrm{NPK}, \mathrm{T}_{2}-100 \% \mathrm{NPK}, \mathrm{T}_{3}-150 \% \mathrm{NPK}, \mathrm{T}_{4}-$ $100 \% \mathrm{NPK}+$ hand weeding, $\mathrm{T}_{5}-100 \% \mathrm{NPK}+$ $\mathrm{ZnSO}_{4} @$ of $25 \mathrm{~kg} \mathrm{ZnSO} \mathrm{ha}^{-1}, \mathrm{~T}_{6}-100 \% \mathrm{NP}$, $\mathrm{T}_{7}-100 \% \mathrm{~N}$ alone, $\mathrm{T}_{8}-100 \% \mathrm{NPK}+\mathrm{FYM} @$ $10 \mathrm{t} \mathrm{ha}^{-1}, \mathrm{~T}_{9}-100 \%$ NPK (-S) and $\mathrm{T}_{10}-$ Absolute control. The hybrid maize variety viz., CO-6 was used as a test crop in Rabi season being $101^{\text {th }}$ crop in finger millet-hybrid maize cropping sequence. The recommended dose of $\mathrm{N}, \mathrm{P}_{2} \mathrm{O}_{5}$ and $\mathrm{K}_{2} \mathrm{O}$ based on initial soil test was 250:75:75 kg ha-1. The sources of $\mathrm{N}, \mathrm{P}$ and $\mathrm{K}$ used were urea, single super phosphate (SSP) and muriate of potash. In sulphur free treatment $\left(\mathrm{T}_{9}\right)$, diammonium phosphate (DAP) was used instead of SSP as a source of P. All the treatments except $\mathrm{T}_{4}$ were sprayed with herbicide Atrazine WP at $500 \mathrm{~g} \mathrm{ha}^{-1}$ at $3^{\text {rd }}$ days after sowing for controlling weeds.

\section{Analysis of soil and plant sample}

Composite surface $(0-15 \mathrm{~cm})$ soil samples were collected from each plot during cropping period (at three critical growth stages of 
hybrid maize viz., knee high, tasselling, milky and harvest). The total $\mathrm{K}$ and available $\mathrm{K}$ was estimated using $\mathrm{HCl}$ extraction method (Jackson, 1973) and neutral normal $\mathrm{NH}_{4} \mathrm{OAc}$ method (Stanford and English, 1949) followed by flame photometry respectively. Among soil $\mathrm{K}$ fractions, water soluble $\mathrm{K}$ was quantified using 1:2 soil: water extraction (Mac Lean, 1960); where in exchangeable K was assessed using neutral normal $\mathrm{NH}_{4} \mathrm{OAc}$ at a soil: extractant ratio of $1: 2.5$ by flame photometry (Stanford and English, 1949). The non-exchangeable $\mathrm{K}$ was estimated by $1 \mathrm{~N}$ $\mathrm{HNO}_{3}$ boiling method (Wood and Deturk, 1940). The difference between total $\mathrm{K}$ and sum of water soluble, exchangeable and nonexchangeable $\mathrm{K}$ gave the amount of lattice $\mathrm{K}$ (Wiklander, 1955).

Besides, plant samples were analysed for potassium content using Tri-acid extraction method followed by flame photometry and expressed as percentage on oven dry basis. The total uptake of $\mathrm{K}$ at different stages of hybrid maize were worked out by multiplying $\mathrm{K}$ content with dry matter production and expressed in $\mathrm{kg} \mathrm{ha}^{-1}$. Finally both straw and grain yield of hybrid maize was recorded at harvest stage. The efficiency of fertilizer potassium applied was computed in term of several indices viz., apparent recovery, physiological efficiency and response ratio using standard formulas.

\section{Statistical analysis}

The data on analysis of soil and plant samples, dry matter production, yield, $\mathrm{K}$ uptake and content of hybrid maize were subjected to analysis of variance (ANOVA) and correlation statistics as suggested by Panse and Sukhatme (1985) to find out the magnitude of treatment effect on various parameters and also to establish possible relationship among soil and plant characteristics in relation to hybrid maize performance. For statistical analysis of data, Microsoft Excel (Microsoft Corporation, USA) and Agres window version 7.0 packages were used.

\section{Results and Discussion}

\section{Soil available $\mathrm{K}$}

The available potassium status of soil was analysed for different critical growth stages of hybrid maize. The overall available potassium content ranged between 471 and $655 \mathrm{~kg} \mathrm{ha}^{-1}$ irrespective of the treatments imposed and stages of hybrid maize. The available $\mathrm{K}$ decreased with advancement in crop growth, the lowest being recorded at harvest due to crop removal. Among treatments, the combined application of FYM with $100 \%$ NPK $\left(\mathrm{T}_{8}\right)$ recorded highest soil available potassium. Such enhanced soil available K status might be due to the application of FYM that generally contains higher amounts of $\mathrm{K}$ $(0.5 \% \mathrm{~K})$ (Krauss, 2002) and the reduction of $\mathrm{K}$ fixation, release of $\mathrm{K}$ from inter lattice space of clay minerals due to interaction of organic matter with clay (Urkurkar et al., 2010). Organic acids of different strength and composition produced during decomposition of applied organic manures could possibly solubilise the fixed potassium from clay matrix resulting an increased availability of $\mathrm{K}$ for crop uptake (Liu and Yao, 2003). Similar results were also recorded by and Liu et al., (2010).

The soil available $\mathrm{K}$ increased with increase in the dose of $\mathrm{K}$ fertilizer application viz., from 50-150\% NPK. The treatment $T_{10}$ (Control) recorded the lowest soil available K. The results further elucidated that soil available $\mathrm{K}$ was significantly higher in treatments that received external source of fertilizer $\mathrm{K}$ compared to treatments without $\mathrm{K}$ viz., absolute control $\left(\mathrm{T}_{10}\right), 100 \% \mathrm{NP}\left(\mathrm{T}_{6}\right)$ and $100 \% \mathrm{~N}\left(\mathrm{~T}_{7}\right)$. The reduction in available 
$\mathrm{K}$ status in such treatments may be due to continuous crop removal and absence of external source of $\mathrm{K}$ fertilizers. Such result coincides with the findings of Laxminarayana (2006).

\section{Total K}

The total $\mathrm{K}$ status in the post-harvest soil of maize varied from 2257 to $3142 \mathrm{mg} \mathrm{kg}^{-1}$. The total $\mathrm{K}$ status of soil was highest in plots under integrated nutrient management and least in control. The exclusion of $\mathrm{K}$ fertilizers from fertilization schedule $(100 \% \mathrm{~N}, 100 \%$ NP) decreased the total K content in soil which is comparable to unfertilized control. This may be due to continuous removal by crop without compensating the $\mathrm{K}$ pools through external supply of $\mathrm{K}$ fertilizers. The total $\mathrm{K}$ content found to increase with graded doses of fertilizers. Similar finding were reported by Suresh et al., (1999) and Murugappan et al., (1998).

Supplemental management practices like hand weeding and $\mathrm{S}$ free sources when combined with $100 \%$ NPK were found to have no effect on total K. However, when $100 \%$ NPK was combined with $\mathrm{ZnSO}_{4}$ there was no noticeable increase in total $\mathrm{K}$ status over $100 \%$ NPK. At higher level of K fertilizer application (150\% NPK), total K was significantly higher than optimal $(100 \%$ NPK) and sub optimal ( $50 \%$ NPK) fertilizer doses.

Assuming that FYM contains $0.5 \% \mathrm{~K}$, this additional application of $\mathrm{K}$ through FYM may have contributed towards increased total $\mathrm{K}$ in treatment receiving $100 \%$ NPK + FYM. Similar findings has been reported by Santhy (1995) who showed the effectiveness of FYM in maintaining higher level of total $\mathrm{K}$ from permanent manurial experiment at Coimbatore.

\section{Soil $\mathbf{K}$ fractions}

\section{Water soluble K}

Among various $\mathrm{K}$ fractions evaluated in the post-harvest soil of hybrid maize, the concentration of water soluble $\mathrm{K}$ was the least with mean value ranged from 20.9 to $26.7 \mathrm{mg}$ $\mathrm{kg}^{-1}$. The result on water soluble $\mathrm{K}$ revealed that its content increased when the rate of NPK applied from 50 to $150 \%$ of optimal level. The reason could be stated as the continuous application of water soluble potassic fertilizers (Deepak Kher and Minhas, 1991). Abedin Mian et al., (1991) and Afroz et al., (2009) found that the concentration of $\mathrm{K}$ in soil solution increased with the increase in the rate of $\mathrm{K}$ application.

Treatments which did not receive $\mathrm{K}(100 \% \mathrm{~N}$, $100 \% \mathrm{NP})$ recorded lower water soluble K. The lowest concentration of water soluble $\mathrm{K}$ was under control. This was due to relatively higher crop uptake in absence of external $\mathrm{K}$ addition. The highest water soluble $\mathrm{K}$ was observed under $100 \%$ NPK+ FYM. This is in conformity with the findings of Sood et al., (2008) who noticed higher water soluble $\mathrm{K}$ in FYM plots and ascribed this to reduction in $\mathrm{K}$ fixation caused by FYM additions due to chelation mechanism.

\section{Exchangeable K}

The data on exchangeable $\mathrm{K}$ revealed that application of FYM along with 100\% NPK recorded higher values of exchangeable-K followed by $150 \%$ NPK treatment. The higher amounts of exchangeable-K in the FYM treated plots over the years may be due to the fact that FYM addition could increase the CEC of soil which was responsible for holding more amount of exchangeable- $\mathrm{K}$ and helped in the release of exchangeable- $\mathrm{K}$ from non-exchangeable pool (Yaduvanshi and Swarup, 2006). 
Application of $150 \%$ NPK also registered higher amount of exchangeable $\mathrm{K}$. This is due to shift in equilibrium by addition of water soluble K sources (Aravind, 1997). Thippeswamy et al., (2000) reported that exchangeable $\mathrm{K}$ increased with increasing $\mathrm{K}$ doses up to $80 \mathrm{~kg} \mathrm{~K} \mathrm{ha}^{-1}$. As in case of water soluble $\mathrm{K}$, withholding $\mathrm{K}$ from schedule resulted in a reduction in exchangeable $\mathrm{K}$ content (Ganeshmmurthy and Biswas, 1995).

\section{Non exchangeable $\mathrm{K}$}

The continuous application of potassic fertilizers at varying levels has consistently maintained the content of non-exchangeable $\mathrm{K}$ at higher level, the highest being in $150 \%$ NPK treatment. This could be ascribed to conversion of added water soluble $\mathrm{K}$ into nonexchangeable forms, increased fixation induced by high levels of $\mathrm{K}$ fertilization and the successive application which might have decreased utilization of non-exchangeable $\mathrm{K}$ leading to its accumulation (Aravind, 1997).

The relatively lower amount of this form of $\mathrm{K}$ in $100 \%$ NPK + FYM treatment could be due to increase in CEC brought about by FYM which in turn accelerated the release of $\mathrm{K}$ from non-exchangeable source by mass action effect (Black, 1968). Exhaustion of K through continuous cropping favoured added $\mathrm{K}$ to enter into non-exhaustible forms (Chakravorti, 1992).

The lowest amount of non-exchangeable $\mathrm{K}$ was noticed in the control treatment. However, the treatments $100 \%$ NP and $100 \%$ $\mathrm{N}$ alone also registered lower amount of nonexchangeable $\mathrm{K}$. When $\mathrm{K}$ fertilizer is not added to soil, the demand for $\mathrm{K}$ increases, finally removal of $\mathrm{K}$ from non-exchangeable fraction occurs thereby reducing this pool of $\mathrm{K}$. This short fall in the level of nonexchangeable $\mathrm{K}$ indicated the role of this fraction in meeting crop $\mathrm{K}$ requirement. These results are in line with the findings of Jayasree Sankar (1994) and Swarup and Wanjari, (2000).

\section{Lattice K}

Among all the $\mathrm{K}$ fractions investigated, lattice $\mathrm{K}$ fraction constitutes about more than $80 \%$ of the total $\mathrm{K}$ in soil with mean value ranged from $1978-2760 \mathrm{mg} \mathrm{kg}^{-1}$. The amount of lattice $\mathrm{K}$ mainly depends on clay mineralogical composition of soil rather than the dynamics among different $\mathrm{K}$ pools. In alluvial soils, where mica is found as dominant mineral, a substantial quantity of $\mathrm{K}$ is released from the mineral structure which provides most of the $\mathrm{K}$ taken up by crops (Singh et al., 2007).

The lattice $\mathrm{K}$ content in the post-harvest soil of hybrid maize revealed higher value (Table 2) in treatment $\mathrm{T}_{8}-100 \% \mathrm{NPK}+\mathrm{FYM}(2760$ $\mathrm{mg} \mathrm{kg}^{-1}$ ) and lowest was recorded under control $\left(\mathrm{T}_{10}\right)$. However the $100 \% \mathrm{NPK}+\mathrm{FYM}$ and $150 \%$ NPK treatments were statistically on par with each other. Graded levels of NPK applied were accompanied by slight increase in lattice $\mathrm{K}$ up to $100 \% \mathrm{NPK}$ (2268 $\mathrm{mg} \mathrm{kg}^{-1}$ ) but higher label of lattice $\mathrm{K}$ while observed in $150 \%$ NPK (2723 $\mathrm{mg} \mathrm{kg}^{-1}$ ). The control and $100 \%$ NP treatments were found to be on par with each other. The lower amount of lattice $\mathrm{K}$ in the absence of $\mathrm{K}$ fertilization slower shift in equilibrium to compensate crop removal and to translocation of clays as reported by Das et al., (1993).

\section{Yield and $\mathrm{K}$ uptake}

\section{Grain yield}

The economic biomass in terms of grain yield of hybrid maize ranged from 3012 to $6057 \mathrm{~kg}$ $\mathrm{ha}^{-1}$ (Table 3 ). The maize grain yield was significantly affected by organic and inorganic fertilizer treatments. 
Table.1 Initial properties of the experimental soil

\begin{tabular}{lc}
\hline Properties & Initial (1972) \\
\hline Particle size distribution & \\
Clay (\%) & 32.6 \\
Silt $(\%)$ & 11.8 \\
Fine sand (\%) & 15.1 \\
Coarse sand (\%) & 39.4 \\
Textural class & Sandy clay loam \\
pH & 8.20 \\
Electrical conductivity $\left(\mathrm{dSm}^{-1}\right)$ & 0.20 \\
Cation exchange capacity $\left(\mathrm{cmol}^{-1}\left(\mathrm{p}^{+}\right) \mathrm{kg}^{-1}\right)$ & 25.2 \\
Organic carbon $\left(\mathrm{g} \mathrm{kg}^{-1}\right)$ & 3.0 \\
Total N $\left(\mathrm{mg} \mathrm{kg}^{-1}\right)$ & 428.0 \\
Total P $\left(\mathrm{mg} \mathrm{kg}^{-1}\right)$ & 490.0 \\
Total K $\left(\mathrm{mg} \mathrm{kg}^{-1}\right)$ & 3964.0 \\
Available nitrogen $\left(\mathrm{kg} \mathrm{ha}^{-1}\right)$ & 178.0 \\
Available phosphorus $\left(\mathrm{kg} \mathrm{ha}^{-1}\right)$ & 11.0 \\
Available potassium (kg ha- & 810.0 \\
Available Zn $\left(\mathrm{mg} \mathrm{kg}^{-1}\right)$ & 2.58 \\
Available Mn $\left(\mathrm{mg} \mathrm{kg}^{-1}\right)$ & 2.74 \\
Available Cu $\left(\mathrm{mg} \mathrm{kg}^{-1}\right)$ & 4.20 \\
Available Fe $\left(\mathrm{mg} \mathrm{kg}^{-1}\right)$ & 2.74 \\
\hline
\end{tabular}

Table.2 Effect of long term fertilization on soil total $\mathrm{K}$ and $\mathrm{K}$ fractions $\left(\mathrm{mg} \mathrm{kg}^{-1}\right)$ in post-harvest soil of hybrid maize

\begin{tabular}{|c|c|c|c|c|c|c|}
\hline \multicolumn{2}{|r|}{ Treatments } & \multirow{2}{*}{$\begin{array}{c}\begin{array}{c}\text { Total } \\
\text { K }\end{array} \\
2734 \\
\end{array}$} & \multirow{2}{*}{$\begin{array}{c}\begin{array}{c}\text { Water } \\
\text { Soluble K }\end{array} \\
22.7 \\
\end{array}$} & \multirow{2}{*}{$\begin{array}{c}\begin{array}{c}\text { Exchangeable } \\
\text { K }\end{array} \\
86.9 \\
\end{array}$} & \multirow{2}{*}{$\begin{array}{c}\begin{array}{c}\text { Non } \\
\text { Exchangeable } \\
\text { K }\end{array} \\
220.4 \\
\end{array}$} & \multirow{2}{*}{$\begin{array}{c}\text { Lattice } \\
\mathbf{K} \\
2204 \\
\end{array}$} \\
\hline $\mathrm{T}_{1}$ & $50 \%$ NPK & & & & & \\
\hline $\mathrm{T}_{2}$ & $100 \%$ NPK & 2619 & 25.2 & 91.5 & 234.9 & 2268 \\
\hline $\mathrm{T}_{3}$ & $150 \%$ NPK & 3102 & 26.1 & 100.6 & 252.5 & 2723 \\
\hline $\mathrm{T}_{4}$ & $100 \% \mathrm{NPK}+\mathrm{HW}$ & 2635 & 24.8 & 92.8 & 229.5 & 2288 \\
\hline $\mathrm{T}_{5}$ & $100 \% \mathrm{NPK}+\mathrm{Zn}$ & 2689 & 23.5 & 92.2 & 227.1 & 2347 \\
\hline $\mathrm{T}_{6}$ & $100 \% \mathrm{NP}$ & 2561 & 21.9 & 81.8 & 193.7 & 2064 \\
\hline $\mathrm{T}_{7}$ & $100 \% \mathrm{~N}$ & 2313 & 21.5 & 79.5 & 188.8 & 2023 \\
\hline $\mathrm{T}_{8}$ & $\begin{array}{l}100 \% \text { NPK + } \\
\text { FYM }\end{array}$ & 3142 & 26.7 & 103.4 & 251.1 & 2760 \\
\hline $\mathrm{T}_{9}$ & $100 \%$ NPK $(-$ S) & 2670 & 24.1 & 94.9 & 226.2 & 2324 \\
\hline $\mathrm{T}_{10}$ & Control & 2257 & 20.9 & 76.3 & 181.6 & 1978 \\
\hline & SEd & 44.79 & 0.37 & 2.29 & 4.70 & 48.68 \\
\hline & $\mathrm{CD}(\mathbf{P}=0.05)$ & 91.10 & 0.75 & 4.45 & 9.34 & 99.30 \\
\hline
\end{tabular}


Table.3 Effect of long-term fertilization on yield and potassium uptake in hybrid maize $\left(\mathrm{kg} \mathrm{ha}^{-1}\right)$

\begin{tabular}{|ll|c|c|c|c|c|}
\hline \multirow{2}{*}{} & \multirow{2}{*}{ Treatments } & \multicolumn{2}{|c|}{ Yield (kg/ha) } & \multicolumn{3}{c|}{ K uptake (kg/ha) } \\
\cline { 2 - 6 } & Straw & Grain & Straw & Grain & Total \\
\hline $\mathbf{T}_{\mathbf{1}}$ & $50 \%$ NPK & 7029 & 5132 & 82.3 & 46.8 & 129.1 \\
$\mathbf{T}_{\mathbf{2}}$ & $100 \% \mathrm{NPK}$ & 8271 & 5378 & 85.9 & 49.1 & 135.0 \\
$\mathbf{T}_{\mathbf{3}}$ & $150 \% \mathrm{NPK}$ & 8514 & 5492 & 87.8 & 51.9 & 139.7 \\
$\mathbf{T}_{\mathbf{4}}$ & $100 \% \mathrm{NPK}+\mathrm{HW}$ & 8149 & 5311 & 85.2 & 48.4 & 133.6 \\
$\mathbf{T}_{\mathbf{5}}$ & $100 \% \mathrm{NPK}+\mathrm{Zn}$ & 8458 & 5432 & 84.5 & 49.2 & 133.7 \\
$\mathbf{T}_{\mathbf{6}}$ & $100 \% \mathrm{NP}$ & 8134 & 5213 & 77.5 & 43.4 & 120.9 \\
$\mathbf{T}_{\mathbf{7}}$ & $100 \% \mathrm{~N}$ & 6933 & 4256 & 76.4 & 42.3 & 118.7 \\
$\mathbf{T}_{\mathbf{8}}$ & $100 \% \mathrm{NPK}+\mathrm{FYM}$ & 9379 & 6057 & 92.7 & 55.7 & 140.4 \\
$\mathbf{T}_{\mathbf{9}}$ & $100 \% \mathrm{NPK}(-\mathrm{S})$ & 8221 & 5349 & 85.4 & 50.5 & 135.9 \\
$\mathbf{T}_{\mathbf{1 0}}$ & Control & 5242 & 3012 & 64.1 & 34.4 & 98.5 \\
\hline & SEd & 165.78 & 114.32 & 1.58 & 0.95 & \\
\hline & CD (P=0.05) & 328.25 & 232.52 & 3.12 & 1.88 & \\
\hline
\end{tabular}

Table.4 Net change in soil K (kg/ha) during 1972-2014 and potassium efficiency indices at harvest stage of Rabi hybrid maize

\begin{tabular}{|l|c|c|c|c|c|c|}
\hline Treatments & $\begin{array}{c}\text { Initial } \\
\text { soil K } \\
(\mathrm{kg} / \mathrm{ha}) \\
(1972)\end{array}$ & $\begin{array}{c}\text { Soil K } \\
\text { (kg/ha) after } \\
\text { 2014Rabi } \\
\text { Hybrid } \\
\text { maize }\end{array}$ & $\begin{array}{c}\text { Net } \\
\text { change in } \\
\text { soil K }\end{array}$ & $\begin{array}{c}\text { Apparent } \\
\text { Recovery } \\
(\%)\end{array}$ & $\begin{array}{c}\text { Physiological } \\
\text { efficiency }\end{array}$ & $\begin{array}{c}\text { Response } \\
\text { Ratio }\end{array}$ \\
\hline $\mathrm{T}_{1}-50 \% \mathrm{NPK}$ & 810 & 521 & -289 & 49.2 & 69.3 & 51.1 \\
\hline $\mathrm{T}_{2}-100 \% \mathrm{NPK}$ & 810 & 535 & -275 & 58.6 & 64.8 & 57.0 \\
\hline $\mathrm{T}_{3-150 \% \mathrm{NPK}}$ & 810 & 584 & -226 & 66.2 & 60.2 & 59.8 \\
\hline $\begin{array}{l}\mathrm{T}_{4}-100 \% \mathrm{NPK} \\
(\mathrm{HW})\end{array}$ & 810 & 550 & -260 & 56.4 & 65.5 & 55.4 \\
\hline $\begin{array}{l}\mathrm{T}_{5}-100 \% \mathrm{NPK} \\
+\mathrm{Zn}\end{array}$ & 810 & 542 & -268 & 56.6 & 68.8 & 58.3 \\
\hline $\mathrm{T}_{6}-100 \% \mathrm{NP}$ & 810 & 507 & -303 & - & 98.3 & - \\
\hline $\mathrm{T}_{7}-100 \% \mathrm{~N}$ & 810 & 499 & -311 & - & 61.6 & - \\
\hline $\begin{array}{l}\mathrm{T}_{8}-100 \% \mathrm{NPK} \\
+\mathrm{FYM}\end{array}$ & 810 & 605 & -205 & 67.3 & 72.7 & 73.4 \\
\hline $\begin{array}{l}\mathrm{T}_{9}-100 \% \mathrm{NPK} \\
(-\mathrm{S})\end{array}$ & 810 & 556 & -254 & 60.1 & 62.5 & 56.3 \\
\hline $\mathrm{T}_{10}$-Control & 810 & 471 & -339 & - & - & - \\
\hline
\end{tabular}


Fig.1 Effect of long term fertilization on soil available K status cropped with hybrid maize

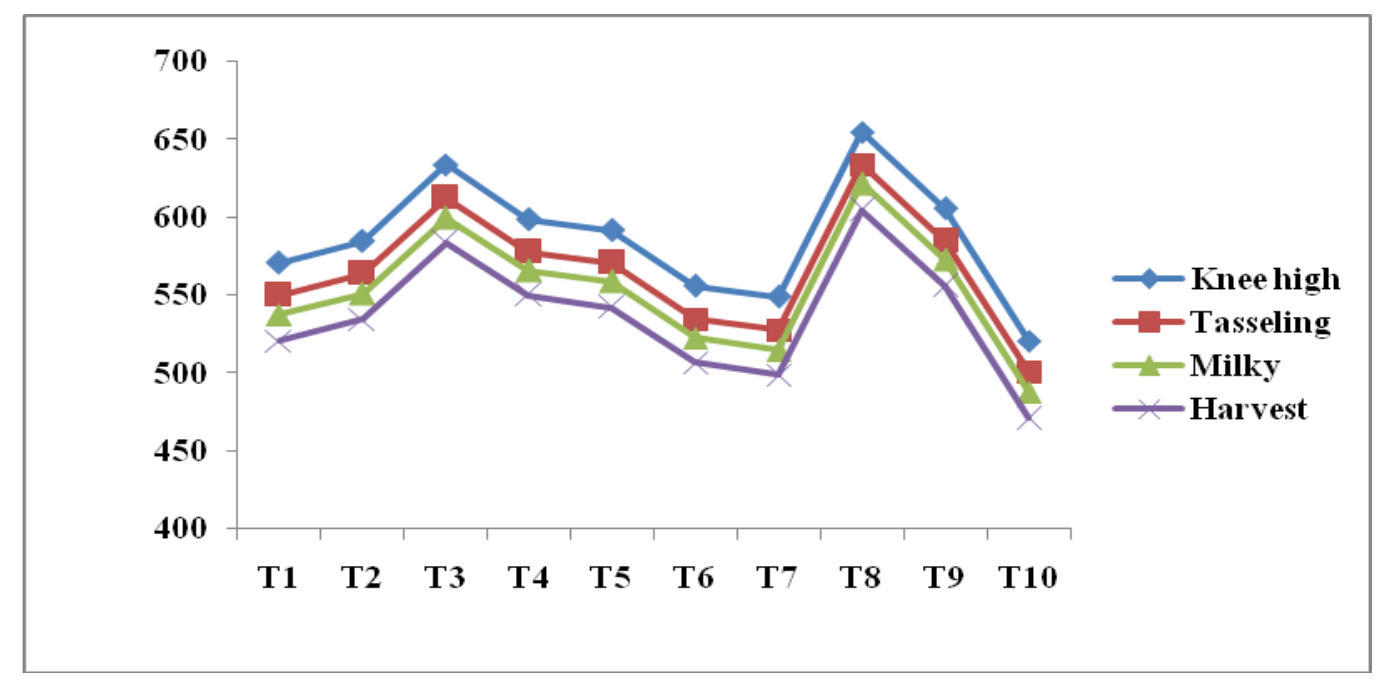

However, the conjoint application of $100 \%$ NPK along with FYM @ $10 \mathrm{t} \mathrm{ha}^{-1}$ registered significantly higher grain yield of maize $\left(6057 \mathrm{~kg} \mathrm{ha}^{-1}\right)$ followed by treatment $\mathrm{T}_{3^{-}}$ $150 \%$ NPK which recorded a grain yield of $5492 \mathrm{~kg} \mathrm{ha}^{-1}$. The integrated application of $100 \%$ NPK along with FYM @ $10 \mathrm{t} \mathrm{ha}^{-1}$ showed an increase in grain yield of $12.6 \%$ over $100 \%$ NPK. Such yield improvement might be attributed to controlled release of nutrients in soil through mineralization of organic manures which in turn would have facilitated better crop growth (Archarya et al., 2012; Shahid et al., 2013).

Progressive increase in grain yield was observed with application of graded levels of NPK addition from 50\% NPK to 150\% NPK (Table 3).Such significant increases in maize yield at high levels of NPK fertilization (Berzsenyi et al., 2000) and due to balanced fertilizer treatments (Belay et al., 2002) under long term crop rotation has been reported in earlier studies (Fig. 1).

The continuous application of $\mathrm{N}$ and $\mathrm{P}$ fertilizers (100\% NP) considerably increased the grain yield $\left(5213 \mathrm{~kg} \mathrm{ha}^{-1}\right)$ compared to application of $\mathrm{N}$ alone $\left(\mathrm{T}_{7}\right)$. Such yield increase might be due to the prolific root growth, enhanced water and nutrient absorption associated with $\mathrm{P}$. This clearly emphasized the need for $\mathrm{P}$ addition for maintaining soil productivity. Similar responses of yield to addition of $\mathrm{P}$ in combination with $\mathrm{N}$ have been reported by Gebrekiden and Seyoum (2006). The application of $\mathrm{N}$ alone has resulted in a conspicuous reduction of $20.9 \%$ in yield than $100 \%$ NPK that in turn emphasizes the essentiality of balanced fertilization to achieve higher productivity (Jia-yin et al., 2013).Withdrawal of $\mathrm{S}$ from fertilizer schedule $\left(T_{9}\right)$ showed no reduction in grain yield as compared to $100 \%$ NPK plot. The lowest grain yield of $3012 \mathrm{~kg} \mathrm{ha}^{-1}$ was registered in control $\left(\mathrm{T}_{10}\right)$ clearly reflected the adverse effect of imbalanced fertilization.

\section{Straw yield}

The straw yield of hybrid maize followed similar trend to that of grain yield. Benefits accruing from the integrated use of FYM with $100 \%$ NPK might be attributed to better supply of nutrients through incorporation of organic manures along with conducive physical environment leading to better root 
activity and higher nutrient absorption which resulted in better crop growth and superior yield attributes responsible for high yield (Thakur et al., 2011; Mishra et al., 2008).

\section{Potassium uptake}

The result on $\mathrm{K}$ uptake by hybrid maize (Table 3) indicated a marked variation in the $\mathrm{K}$ uptake by hybrid maize due to the variation in fertilizer treatments imposed. The treatment receiving 100\% NPK+FYM@10 t $\mathrm{ha}^{-1}\left(\mathrm{~T}_{8}\right)$ recorded the highest total $\mathrm{K}$ uptake of $140.4 \mathrm{~kg} \mathrm{ha}^{-1}$ with a mean $\mathrm{K}$ uptake of 92.7 and $55.7 \mathrm{~kg} \mathrm{ha}^{-1}$ in straw and grain respectively which differed significantly when compared to all other treatments. Such high $\mathrm{K}$ uptake in FYM treated plots may be attributed to solubilisation of native soil $\mathrm{K}$, chelation, mobilization and their accumulation in different plant parts. The straw and grain $\mathrm{K}$ uptake in treatment $\mathrm{T}_{6^{-}}$ $100 \% \mathrm{NP}$ and $\mathrm{T}_{7}-100 \% \mathrm{~N}$ alone was comparable to $\mathrm{K}$ uptake in plots receiving 100 $\%$ NPK $\left(\mathrm{T}_{2}\right)$. This might be due to the nonlimiting $\mathrm{K}$ supply from the native soil which was rich in $\mathrm{K}$ (with an available $\mathrm{K}$ of $810 \mathrm{~kg}$ $\mathrm{ha}^{-1}$ ) and higher biomass yield due to continuous application of nitrogenous fertilizers. Total $\mathrm{K}$ uptake in control $\left(\mathrm{T}_{10}\right)$ as well as $\mathrm{N}$ alone treatments $\left(\mathrm{T}_{7}\right)$ were very low owing to low dry matter yields even though the soil supply with respect to $\mathrm{K}$ was nonlimiting (Mishra et al., 2008).

\section{Potassium efficiency indices}

The efficiency of potassium was computed in term of several indices viz., apparent recovery, physiological efficiency and response ratio (Table 4).

\section{Apparent K recovery}

The apparent $\mathrm{K}$ recovery indicates per cent recovery of added K by crop. Striking differences were observed in apparent $\mathrm{K}$ recovery for different fertilizer treatments which varied from 32.5 to $67.3 \%$ highest being recorded in treatment receiving $100 \%$ NPK with FYM $\left(\mathrm{T}_{8}\right)$. Cassman et al., (2002) computed $\mathrm{K}$ fertilizer recovery under different cropping systems and reported $37 \% \mathrm{~K}$ recovery for corn. Hence the results indicated that per cent recovery of $\mathrm{K}$ enhanced when there is application of both inorganic $\mathrm{K}$ fertilizers and organics in a combined form. This coincides with findings of Chesti et al., (2013) who reported a potassium recovery of $101 \%$ at $100 \%$ NPK and was still higher of $117 \%$ at $100 \%$ NPK applied with $10 \mathrm{t}$ FYM $\mathrm{ha}^{-1}$.

\section{Physiological efficiency}

The quantity of grains produced in response to the quantity of $\mathrm{K}$ uptake by crop is expressed as physiological efficiency which showed conspicuous variation among treatments with mean value ranging from 60.2 to 98.3 respectively. Among treatments, $\mathrm{T}_{6^{-}}$ $100 \%$ NP showed higher K efficiency of 98.3 and lowest was recorded in $\mathrm{T}_{3}-150 \%$ NPK (Table 4). The treatment $\mathrm{T}_{8}$ with application of $\mathrm{K}$ fertilizers in combination with FYM also recorded a higher K efficiency of 72.7.

\section{Response ratio}

The response ratio which is an indicator of the grain produced per $\mathrm{kg}$ of applied nutrient showed an average $K$ response ranging from 51.1 to 73.4 at harvest stage of hybrid maize (Table 4). Application of 100\% NPK along with FYM $\left(\mathrm{T}_{8}\right)$ recorded the highest response ratio (73.4) while 50\% NPK $\left(\mathrm{T}_{1}\right)$ accounted for lowest response ratio (51.1). With the graded levels of fertilizers from sub optimal (50\% NPK) to super optimal (150\% NPK) there is gradual increase in response ratio for $\mathrm{K}$. The results indicate that the response for $\mathrm{K}$ is high at higher dose of $\mathrm{K}$ fertilizer 
application. This is supported by findings of Saravanan (1990) who reported that response ratio increased with increase in fertilizer doses. It is also observed that among treatments, increase in grain $(\mathrm{kg})$ for $\mathrm{kg}$ of $\mathrm{K}$ applied was higher with combined application of $100 \%$ NPK with FYM $\left(\mathrm{T}_{8}\right)$.

Hence, adequate and balanced application of $\mathrm{K}$ fertilizer nutrients is a key for improving the efficiency of applied K fertilizers.

The results obtained from the present study on long-term fertilization under finger milletmaize cropping sequence revealed that application of $100 \%$ NPK in combination with FYM @ $10 \mathrm{t} \mathrm{ha}^{-1}$ improved potassium fractions in soil over control emphasizing the importance of organic manure in transformations of different $\mathrm{K}$ fractions in soil. Grain and straw yield of hybrid maize were significantly higher under $100 \%$ NPK + FYM treatment which is well evidenced by a yield increase of $12.6 \%$ over $100 \%$ NPK alone. The results on change in soil available K over a period from 1972-2014 under continuous cropping depicts a negative balance of $\mathrm{K}$ in soil irrespective of fertilizer treatments imposed, lowest (- $\left.205 \mathrm{~kg} \mathrm{ha}^{-1}\right)$ being recorded in $100 \% \mathrm{NPK}+\mathrm{FYM}$ plots $\left(\mathrm{T}_{8}\right)$. Therefore, the present investigation stresses the vital importance of application of chemical fertilizers in conjunction with organic manures in the fertilizer schedule in exploiting high yield potential of hybrid maize through its favorable effect on $\mathrm{K}$ supply and maintaining soil $\mathrm{K}$ dynamics so as to sustain soil productivity over long run.

\section{References}

Abedin Mian, M.J., H.P. Blume, Z.H. Bhuiyan and M. Eaqub. 1991. Water and nutrient dynamics of a paddy soil of Bangladesh. Z. Planzenemahr. Bodenk, 154: 93-99.
Afroz, D., M.J. Abedin Mian, M.A. Hossain and E.S. Rashid. 2009. Effects of split application of potassium on yield and potassium balance for boro rice (BRRI dhan 29). International Journal of Biological Research, 7: 73-79.

Aravind, S., 1997. Evaluation of dynamics of soil $\mathrm{K}$ and physical properties under continuous fertilization and cropping. M.Sc. (Ag.) Thesis, Tamil Nadu Agricultural University, Coimbatore.

Archaya, R., A.K. Dash and H.K. Senapati. 2012. Effect of integrated nutrient management on microbial activity influencing grain yield under rice-rice cropping system in an acid soil. Asian Journal of Microbiology, Biotechnology and Environmental Sciences, 14: 36368.

Belay, A., A. Claassens and F. Wehner. 2002. Effect of direct nitrogen and potassium and residual phosphorus fertilizers on soil chemical properties, microbial components and maize yield under long-term crop rotation. Biology and Fertility of Soils, 35(6): 420-427.

Berzsenyi, Z., B. Gyorffy and D.Q. Lap. 2000. Effect of crop rotation and fertilisation on maize and wheat yields and yield stability in a long-term experiment. European Journal of Agronomy, 13(2-3): 225-244.

Black, C.A., 1968. Soil plant relationship, 2nd Ed. John Wiley and Sons, Inc. New York, London, pp: 403-414.

Brar, B.S., and N.S. Pasricha. 1998. Longterm studies on integrated use oforganic and inorganic fertilisers in maize-wheatcowpea cropping system on alluvial soils of Punjab. In: Long-Term Soil Fertility Management through Integrated Plant Nutrient Supply (Eds). A. Swarup, D. Damoder Reddy and R.N. Prasad. Indian institute of Soil Science, Bhopal, India. pp: 154-168.

Cassman, K.G., A. Dobermann and D.T. 
Walters. 2002. Agroecosystems, nitrogen use efficiency, and nitrogen management. Ambio, 31: 132-140.

Chakravorti, S.P., 1992. Different forms of soil $\mathrm{K}$ as influenced by $\mathrm{K}$ application in normal and K exhausted soil. Journal of Indian Society of Soil Science, 40: 271276.

Chesti, M.H., Anshuman Kohli and A.K. Sharma. 2013. Effect of integrated nutrient management on yield and nutrient uptake by wheat (Triticum aestivum) and soil properties under intermediate zone of Jammu and Kashmir. Journal of Indian Society of Soil Science, 61(1):1-6.

Das, K., S.K. Singh and R.L. Shyampura. 1993. Forms of potassium in relation to land form and soil properties of Basaltic Terrain. Journal of Indian Society of Soil Science, 41(2):557-559.

Deepak Kher, and R.S. Minhas.1991. Changes in the forms of potassium with continuous manuring and cropping. Journal of Indian Society of Soil Science, 39: 365-367.

Ganeshmoorthy, A.N., and C.R. Biswas. 1995. Contribution of potassium from non-exchangeable source in soil to crops. Journal of Indian Society of Soil Science, 33: 60-66.

Gebrekiden, H., and M. Seyoum. 2006. Effects of mineral $\mathrm{N}$ and $\mathrm{P}$ fertilizers on yield and yield components of flooded lowland rice on Vertisols of fogera plain. Journal of Agriculture and Rural Development in the Tropics and Subtropics, 107: 161-176.

Jackson, M.L., 1973. Soil chemical analysis. Prentice Hall of India Private Ltd., New Delhi. pp: 56-70.

Jayashree Sankar, S., 1994. Investigations on NPK fractions under long term fertilization in an irrigated Inceptisol. Ph.D. Thesis, submitted to Tamil Nadu
Agricultural University, Coimbatore.

Jia-yin, D.U., R.U. Mei and N.I. Wu-Zhong. 2013. Effects of fertilization with reducing nitrogen, controlling phosphorous and stabilizing potassium on rice yield and nutrient accumulation. Plant Nutrition and Fertilizer Science, 19: 523-533.

Krauss, A., 2002. Soil potassium mining in the WANA region, a matter of concern Proceedings of the Eighth AFA International Annual Conference, 29-31 January 2002, Cairo, Egypt.

Laxminarayana, K., 2006. Effect of integrated use of inorganic and organic manure on soil properties, yield and nutrient uptake of rice in Ultisols of Mizoram. Journal of Indian Society of Soil Science, 54(1): 120-123.

Liu, E., C. Yan, X. Mei, W. He, S.H. Bing, L. Ding, Q. Liu, S. Liu and T. Fan. 2010. Long- term effect of chemical fertilizer, straw, and manure on soil chemical and biological properties in northwest China. Geoderma, 158(3-4): 173-180.

Liu, S.T., and Y.X. Yao. 2003. Effects of long-term fertilization on dynamics of phosphorus and potassium in soil. Ecology and Environment, 4: 452-455 (in Chinese).

Mac Lean, A.J., 1960. Water soluble potassium percent $\mathrm{K}$ saturation and $\mathrm{pK}$ $1 / 2 \mathrm{p} \quad(\mathrm{Ca}+\mathrm{Mg})$ as indices of management effects on $\mathrm{K}$ status of soils. Trans. $7^{\text {th }}$ International Congress on Soil Science, Madison, WI. pp: 86-91.

Mengel, K., 1985. Dynamics and availability of major nutrients in soils. Advances in Soil Science, 2: 65-131.

Mishra, B., A. Sharma, S.K. Singh, J. Prasad and B.P. Singh. 2011. Influence of continuous application of amendments to maize-wheat cropping system on dynamics of microbial biomass in Alfisol of Jharkhand. Journal of Indian Society of Soil Science., 56: 71-75. 
Mishra, B., A. Sharma, S.K. Singh, J. Prasad and B.P.Singh. 2008. Influence of continuous application of amendments to maize-wheat cropping system on dynamics of soil microbial biomass in Alfisol of Jharkhand. Journal of the Indian Society of Soil Science, 56: 7175.

Murugappan, V., P. Santhy, D. Selvi and Raniperumal. 1998. Long term fertilizer experiment with intensive cropping on an Inceptisol. In: Proc. National workshop, 2-4 April, at Indian Institute of Soil Science, Bhopal. pp: 194-205.

Panse, V.G., and P.V. Sukhatme. 1985. Statistical Methods for Agricultural Workers. Publication and information division. ICAR, New Delhi.

Santhy, P., 1995. Studies on organic matter, NPK fractions and their influence on soil fertility and crop yield under long term fertilization. Ph.D. Thesis, submitted to Tamil Nadu Agricultural University, Coimbatore.

Santhy, P., P. Muthuvel, V. Murugappan and D. Selvi. 1998. Long term effects of continuous cropping and fertilization on crop yields and soil fertility status. Journal of Indian Society of Soil Science, 46(3): 391-395.

Saravanan, A., 1990. $\mathrm{N}^{15}$ studies on nitrogen use efficiency and balance in rice soil system. M. Sc. (Ag). Thesis submitted to TNAU, Coimbatore.

Shahid, M., A.K. Shukla, R. Tripathy, A. Kumar, S. Mohanty, P. Bhattacharyya, R. Raja and B.B. Panda. 2013. Longterm effects of fertilizers and manure applications on soil quality and yields in a sub humid tropical rice-rice system. Soil Use and Management, 29: 322-332.

Singh, Akhilesh Kumar, A.K. Sarkar, Kumar, Arvind and B.P. Singh. 2009. Effect of long-term use of mineral fertilizers, lime and farmyard manure on the crop yield, available plant nutrient and heavy metal status in acidic loam soil. Journal of the Indian Society of Soil Science, 57: 362-365.

Singh, M., S.R. Reddy, V.P. Singh and T.R. Rupa. 2007. Phosphorus availability to rice (Oryza sativa L.) - wheat (Triticum aestivum L.) in a Vertisol after eight years of inorganic and organic fertilizer additions. Bioresource Technology., 98: 1474-1481.

Sood, B., S.K. Subehia and S.P.Sharma. 2008. Potassium fractionsin acid soil continuously fertilized with mineral fertilizers and amendments under maize-wheat cropping system. Journal of Indian Society of Soil Science, 56: 54-58.

Srinivasa Rao, A., Subba Rao and T.R. Rupa.2001. Need for inclusion of nonexchangeable potassium as a measure in soil test calibration and potassium recommendations. Fertiliser News, 46(5): 31-38.

Stanford, S., and L. English. 1949. Use of flame photometer in rapid soil tests of K. Canadian Journal of Agronomy., 41: 446-447.

Suresh, S., S. Subramanian and T. Chitdeswari. 1999. Effect of Long Term Fertilization and manuring on yield of Sorghum (Sorghum bicolour) - Cumbu (Pennisetum glaucum) in rotation on Vertisol under Dry farming and soil properties. Journal of the Indian Society of Soil Science, 47(2): 272-276.

Swarup, A., 1998. Emerging soil fertility management issues for sustainable crop production in irrigated systems. In: Long-Term Soil Fertility Management through Integrated Plant Nutrient Supply. (Eds). A. Swarup, D. Damodar Reddy and R.N. Prasad. Indian Institute of Soil Science, Bhopal, India. pp: 5468.

Swarup, A., and A.N. Ganeshmurthy. 1998. Emerging nutrient deficiencies under 
intensive cropping systems and remedial measures for sustainable high productivity. Fertiliser News, 43(7): 3750.

Swarup, A., and R.H. Wanjari. 2000. Three decades of All India Coordinated Research Project on Long-Term Fertilizer Experiment to Study Changes in Soil Quality, Crop Productivity and Sustainability. Indian Institute of Soil Science, Bhopal, India.

Thakur, R., S.D. Sawarkar, U.K. Vaishya and M. Singh. 2011. Impact of continuous use of inorganic fertilizers and organic manure on soil properties and productivity under soybean-wheat intensive cropping of a Vertisol. Journal of Indian Society of Soil Science, 59: 74-81.

Thippeswamy, H.M., B.G. Shivakumar and S.S. Balloli. 2000. Potassium transformation studies in lowland rice (O. sativa L.) as influenced by levels and time of $\mathrm{K}$ application. Journal of Potassium Research, 16: 7-11.

Urkurkar, J.S., A. Tiwari, Chitale, Shrikant and R.K. Bajpai. 2010. Influence of long term use of inorganic and organic manures on soil fertility and sustainability of rice and wheat in Inceptisols. Indian Journal of Agricultural Sciences, 80: 208-212.

Wang, J.J., D.L. Harrell and P.F. Bell. 2004. Potassium buffering characteristics of three soils low in exchangeable potassium. Journal of Soil Science Society of America, 68: 654-661.

Wiklander, L., 1955. Forms of potassium in soils. Potassium symposium.1954: pp: 109-121.

Wood, L.K., and E.E. Deturk. 1940. Adsorption of ammonium and potassium in non-replaceable form. Soil Science Society of America Proceedings, 25(2): 101-104.

Yaduvanshi, N.P.S., and A. Swarup.2006. Effect of long-term fertilization and manuring on potassium balance and non-exchangeable $\mathrm{K}$ release in a reclaimed sodic soil. Journal of Indian Society of Soil Science, 54:203-207.

\section{How to cite this article:}

Pragyan Paramita Rout, N. Chandrasekaran, K. Arulmozhiselvan and Dhaneshwar Padhan. 2017. Effect of Long Term Fertilization on Soil K Dynamics and Uptake by Hybrid Maize in an Irrigated Inceptisol under Intensive Cropping. Int.J.Curr.Microbiol.App.Sci. 6(10): 10491061. doi: https://doi.org/10.20546/ijcmas.2017.610.127 